\title{
Ø \\ THE \\ Debris Basin and Deflection Berm Design for Fire-Related Debris-Flow Mitigation
}

GEOLOGICAL

SOCIETY

OF AMERICA ${ }^{\circledR}$

\author{
ADAM B. PROCHASKA ${ }^{1}$
}

PAUL M. SANTI

JERRY D. HIGGINS

Colorado School of Mines, Department of Geology and Geological Engineering, 1516 Illinois Street, Golden, CO 80401

Key Terms: Debris Flow, Fire-Related, Mitigation, Design, Basin, Deflection Berm

\begin{abstract}
Debris flows are hazardous because of their poor predictability, high impact forces, and ability to deposit large quantities of sediment in inundated areas. To minimize the risk to developments on alluvial fans, debris-flow mitigation structures may be required. This study reviewed the state of practice for the design of two types of debris-flow mitigation structures: basins and deflection berms. Published guidelines for these structures are rare, and there appears to be little standardization. Recommended design improvements, particularly for fire-related debris flows, include incorporating several recent developments in debrisflow mitigation design, reducing subjectivity, and enhancing the technical basis for the designs. Specific shortcomings of existing design methodologies include techniques for predicting debris-flow volume, specifications for berm geometry, impact loading considerations, and lack of flexibility in outlet works design, among others. Proposed solutions and guidelines for these issues are presented.
\end{abstract}

\section{INTRODUCTION}

With an ever increasing population, urban development will need to further encroach into geologically hazardous areas. One such example of a hazardous area is an alluvial fan, which may be susceptible to debris flows. VanDine (1985) defines a debris flow as being "a mass movement that involves water-charged, predominantly coarse-grained inor-

${ }^{1}$ Present Address: RJH Consultants, Inc., 9800 Mt. Pyramid Court, Suite 330, Englewood, CO 80112. Phone: 303-225-4611, Fax: 303-2254615 . ganic and organic material flowing rapidly down a steep, confined, preexisting channel." Debris flows are hazardous because of their poor predictability, high impact forces, and ability to deposit large quantities of sediment in inundated areas (Jakob and Hungr, 2005).

Debris-flow hazards increase following a forest fire because of the increased rainfall runoff and soil erodibility that result from the removal of vegetation (Cannon and Gartner, 2005). McDonald and Giraud (2002) and Giraud and McDonald (2007) describe the impacts of recent fire-related debris flows in Utah. Fire-related debris flows initiated from several recently burned drainages on Dry Mountain in 2002 and 2004. These flows inundated a subdivision near Santaquin (Figure 1) and caused $\$ 500,000$ in damage to 32 homes.

To minimize the risk to developments on alluvial fans, debris-flow mitigation structures may be required. Two types of mitigation structures are debrisflow basins and deflection berms. Debris-flow basins are closed structures that are designed to contain all or much of the volume of a debris flow. Deflection berms are open structures that are designed to direct debris flows toward low-risk areas on alluvial fans. Current technical literature describes different debris-flow mitigation structures and also presents equations for the estimation of design parameters, but do not specifically outline how the design equations should be incorporated into the design of the structures. One of the few published systems, by Los Angeles (L.A.) County (Easton et al., 1979; Nasseri et al., 2006), includes standard procedures for the design of debrisflow basins and could benefit from several recent developments in debris-flow mitigation design. No guidelines exist for the design of debris-flow deflection berms; government agencies have been using design procedures that contain a degree of subjectivity and could benefit from a more robust technical basis.

This article first briefly summarizes debris-flow mitigation design aspects reported in the technical 


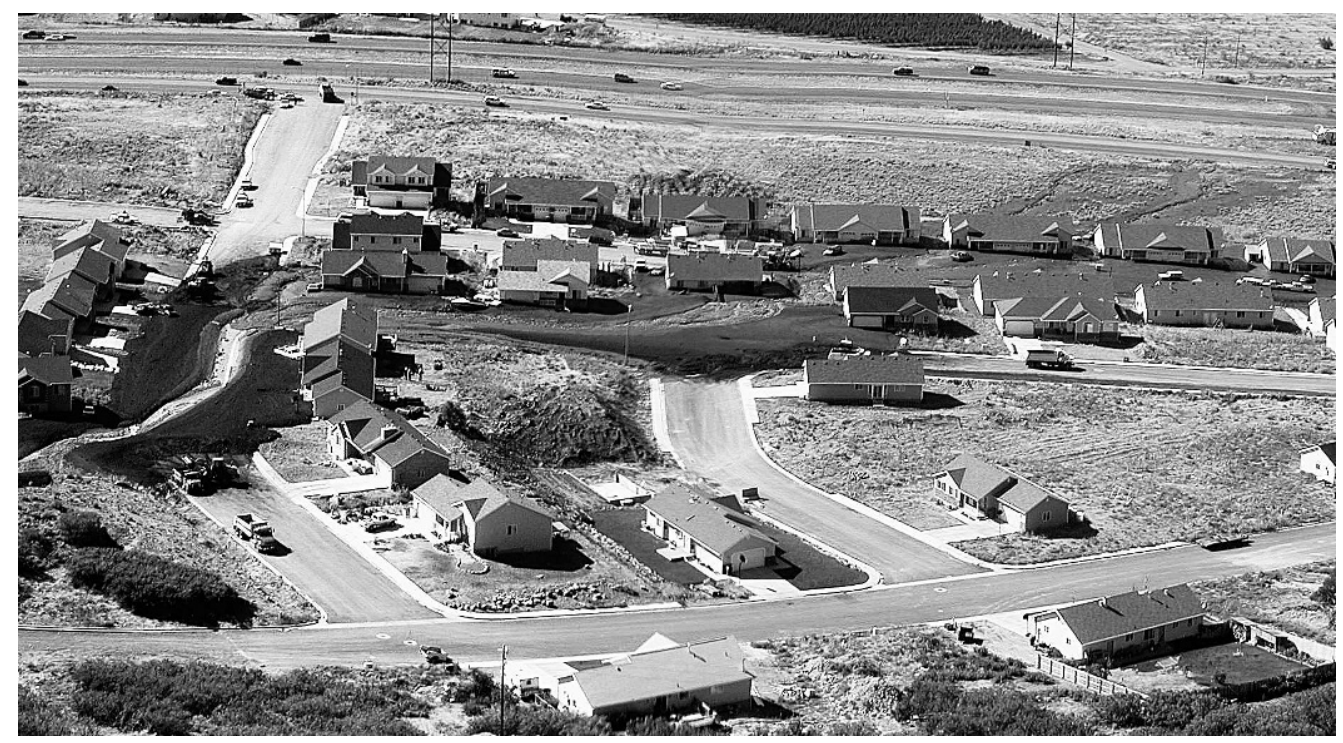

Figure 1. Inundation of a subdivision near Santaquin, Utah, by fire-related debris flows (from Elliot, 2007).

literature. Next, a detailed review is presented of the design methodology for L.A. County debris basins (Easton et al., 1979; Nasseri et al., 2006) and the deflection berm design policies of the Oregon Department of Forestry (Hinkle, 2007) and the Natural Resources Conservation Service (NRCS) (Rogers, 2007). These procedures are some of the only published systems available and are fairly specific to the geology and conditions for which they were prepared. Finally, potential improvements for these design methodologies with respect to recent developments in debris-flow mitigation design are presented, specifically for fire-related debris flows. A quantitative methodology for the design of deflection berms is also presented.

\section{BACKGROUND}

Discussion of various debris-flow mitigation structures can be found in several sources within the technical literature (Hungr et al., 1987; VanDine, 1996; Fiebiger, 1997; VanDine et al., 1997; Heumader, 2000; and Huebl and Fiebiger, 2005). Equations to aid in the design of these mitigation structures have been outlined by various authors (Hungr et al., 1984; VanDine, 1996; and Lo, 2000). However, none of these sources gives detailed guidelines as to how the debris-flow characteristics that are estimated from the design equations should be incorporated into the design of the mitigation structures.

Giraud (2005) provides guidelines for evaluating the debris-flow hazard of areas, but focuses primarily on the geological aspects of debris-flow occurrence and not on the actual design of mitigation. VanDine (1996) includes conceptual sketches of different mitigation structures, but does not provide a direct way of estimating the required size and strength of the conceptual structures based on properties of the debris flow. Sun and Lam (2004) provide a simplified methodology for the design of various debris flow barriers (concrete walls, gabions, and fences). Various possible locations for barrier placement are determined from the channel profile and the anticipated event volume. The required barrier size and strength at each location are also dependent on the design volume. However, this design method is limited to debris flows with volumes less than $600 \mathrm{~m}^{3}$ (Sun and Lam, 2004). Bradley et al. (2005) discuss the design of debriscontrolling structures, but these designs are only applicable to debris carried by normal streamflow.

Specific design methods for debris-flow basins and deflection berms will be looked at in detail and are assumed to represent the state of practice in general. L.A. County has developed detailed manuals for the design of debris basins (Easton et al., 1979; Nasseri et al., 2006), but these manuals do not include several aspects of debris-flow mitigation design that are found in recent technical literature. In Oregon, deflection berms used in forested regions are subjectively designed, using conservative qualitative judgment. The NRCS applies a bulking factor to clearwater flow to design the flow capacity of deflection berms. Several designers of other debris-flow mitigation structures recently constructed in Colorado were also contacted, but they declined to respond with their design methodologies. 


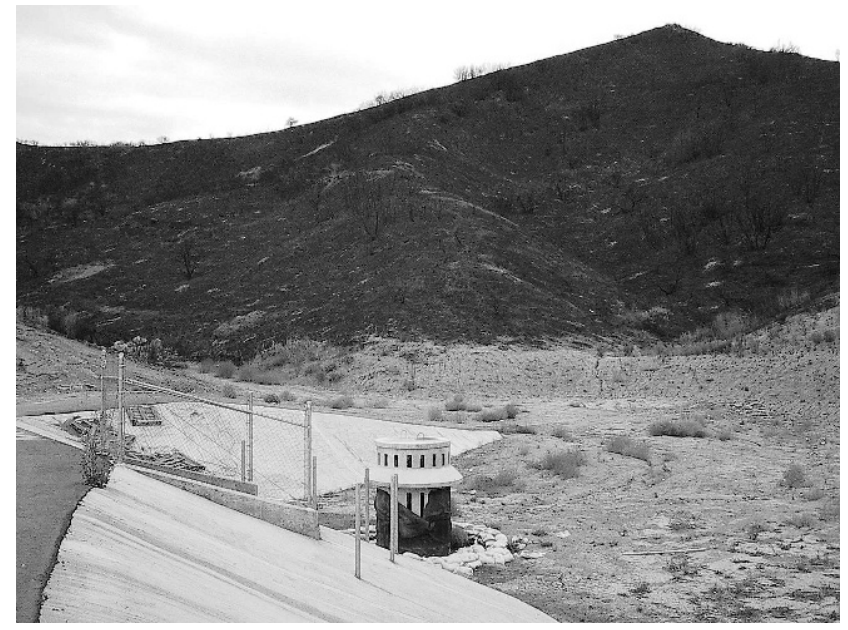

Figure 2. Photo of the Dewitt Canyon Debris Basin in L.A. County (courtesy of Ben Willardson).

\section{STATE OF PRACTICE FOR DEBRIS-FLOW BASIN DESIGN}

L.A. County has developed detailed manuals for the design of debris-flow basins (Easton et al., 1979; Nasseri et al., 2006), which are the only readily available designs the authors could find. A photograph of the Dewitt Canyon Debris Basin in L.A. County, which was designed using the procedures outlined by Easton et al. (1979) and Nasseri et al. (2006), is shown in Figure 2. The main components of these basins are an earthen berm, a debris barrier, a spillway, and an outlet works, the general layout of which is shown in Figure 3. The published design procedures for each of these components are presented in upcoming sections. A predicted debris-flow volume is the primary event characteristic used for sizing and siting the basin. L.A. County's current method of estimating debris-flow volume is presented in the next section.

\section{Predicted Debris-Flow Volume}

L.A. County design manuals specify that a debrisflow basin is to have a capacity equal to the Design Debris Event (DDE), which is the "quantity of sediment produced by a saturated watershed significantly recovered from a burn (after four years) as a result of a 50-year, 24-hour rainfall amount" (Nasseri et al., 2006). The DDE is estimated from the area of a drainage basin area and its Debris Production curve. L.A. County is divided into 11 different Debris Production Areas (DPAs) based on local geologic, topographic, vegetative, and rainfall characteristics; these different DPAs are mapped in Appendix A of Nasseri et al. (2006). Each DPA has an associated
Debris Production curve; an example of the Debris Production curves for the Los Angeles Basin is shown on Figure 4.

In the simplest case of an undeveloped basin, the predicted debris-flow volume is equal to the drainage area multiplied by the Debris Production rate for the appropriate DPA. Nasseri et al. (2006) provide additional equations to obtain weighted-average predicted volumes for drainage basins that are partially developed, fall within multiple DPAs, or contain existing sediment control structures.

\section{Basin Siting and Sizing}

Nasseri et al. (2006) provide an iterative technique through which the required height and location of the berm of a debris basin can be identified, based on the predicted debris-flow volume. This procedure is in agreement with other design recommendations (Hungr et al., 1987; VanDine, 1996; and Deganutti et al., 2003), and thus will not be discussed further.

\section{Debris Berm Specifications}

Easton et al. (1979) provide detailed specifications for the earthen berm of the debris basin. The berm is to have a crest width of $20 \mathrm{ft}(6.1 \mathrm{~m})$ and side slopes of 3:1 (horizontal:vertical). Steeper slopes are allowable if adequate stability is demonstrated when the berm is analyzed according to small-dam design criteria. The crest is specified to rise from the spillway walls to each abutment with a slope equal to 60 percent of the natural channel slope within the basin. The upstream face of the berm is to be protected by a 6 -in. $(15-\mathrm{cm})$ thick concrete slab with No. 5 rebar placed on 18-in. (46-cm) centers in both directions. The downstream face of the berm is specified to be seeded to protect against erosion. The horizontal length of the berm foundation should be sufficiently long to preclude piping.

\section{Debris Barrier Specifications}

Easton et al. (1979) specify that a debris barrier consisting of vertical members should be provided upstream of the spillway to prevent it from clogging with debris. The barrier is specified to be at least $6 \mathrm{ft}$ $(1.8 \mathrm{~m})$ upstream of the spillway. The top of the barrier should be $1 \mathrm{ft}(0.3 \mathrm{~m})$ below the water surface elevation that would be required to pass the design water discharge through the spillway. At least $2 \mathrm{ft}(0.6 \mathrm{~m})$ of freeboard is required between this water surface elevation and the crest of the 
a
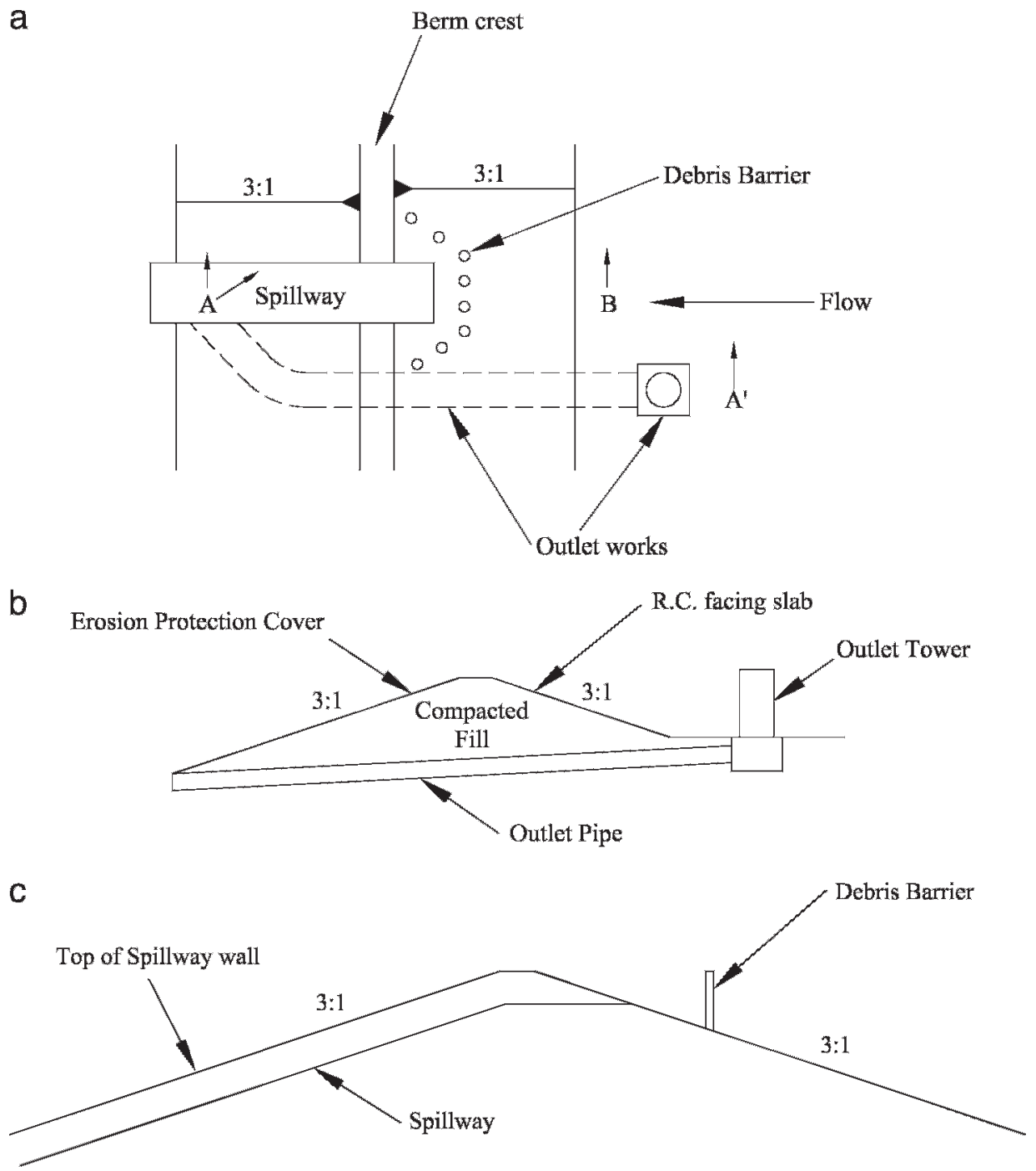

Figure 3. Layout of L.A. County's debris basin components (not to scale) (after Easton et al., 1979): (a) Plan view, (b) Section A-A', and (c) Section A-B.

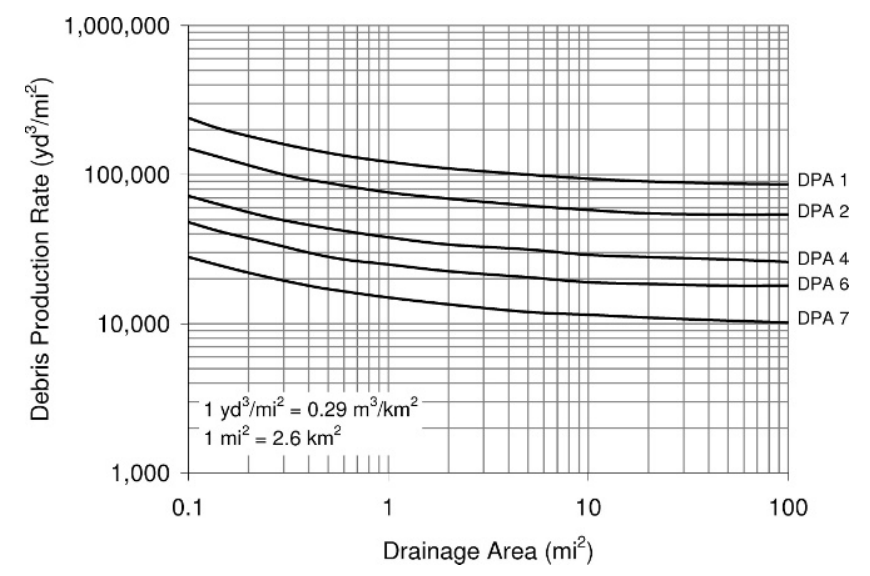

Figure 4. Debris Production curves for the DPAs within the Los Angeles Basin (after Nasseri et al., 2006). debris berm. Horizontal spacings between barrier members are specified to be less than the lesser of $4 \mathrm{ft}(1.2 \mathrm{~m})$ or two-thirds of the conduit width at the downstream end of the spillway. The barrier is specified to be designed for an equivalent fluid pressure of $62.5 \mathrm{lb} / \mathrm{ft}^{2}(3.0 \mathrm{kPa})$ along its entire length (i.e., it is completely plugged). This load is assumed to be temporary, and thus the allowable stresses within the barrier members are increased by one-third. The depth of embedment of the barrier members is calculated as a function of the applied moment and the barrier diameter (Easton et al., 1979).

\section{Spillway Specifications}

Easton et al. (1979) provide specifications for the spillway capacity and also for the design of the 
Table 1. Freeboard and Factor of Safety recommendations (after FEMA, 1995).

\begin{tabular}{lcc}
\hline \hline \multicolumn{1}{c}{ Type of Flooding } & Freeboard (ft) & Impact Factor of Safety \\
\hline Shallow water flooding, $<1 \mathrm{ft}$ & 1 & 1.1 \\
Moderate water flooding, $<3 \mathrm{ft}$ & 1 & 1.2 \\
Moderate water flooding, $<3 \mathrm{ft}$ with potential for debris, rocks $<1 \mathrm{ft}$ diameter and sediment & 1 & 1.2 \\
Mud floods, debris flooding $<3 \mathrm{ft}$, minor surging and deposition, $<1 \mathrm{ft}$ boulders & 2 & 1.25 \\
Mud flows, debris flows $<3 \mathrm{ft}$, surging, mud levees, $>1 \mathrm{ft}$ boulders, minor waves, deposition & 2 & 1.4 \\
Mud and debris flows $>3 \mathrm{ft}$, surging, waves, boulders $>3 \mathrm{ft}$, major deposition & 3 & 1.5 \\
\hline
\end{tabular}

Note: $1 \mathrm{ft}=0.3 \mathrm{~m}$.

spillway walls and invert slab. This existing procedure designs the spillway for extreme flow events and is appropriate with respect to the Federal Emergency Management Agency's (FEMA's) (1995) freeboard recommendations (Table 1), and thus will not be discussed further.

\section{Outlet Works Specifications}

Easton et al. (1979) specify that the outlet works should consist of an outlet tower and an outlet pipe capable of passing $150 \mathrm{ft}^{3} / \mathrm{s} \quad\left(4.2 \mathrm{~m}^{3} / \mathrm{s}\right)$ via nonpressurized flow. The outlet tower should be located at the lowest point of the basin (but not within the direct path of flow between the basin inlet and the spillway) and should extend at least $1 \mathrm{ft}(0.3 \mathrm{~m})$ above the predicted surface of deposited debris within the basin. The outlet pipe is to be at least 36 in. $(91 \mathrm{~cm})$ in diameter and should have a slope greater than five percent to prevent siltation. Easton et al. (1979) and L.A. County (2005) provide structural details for the standard outlet works design.

\section{Miscellaneous Specifications}

Easton et al. (1979) provide requirements for engineering geology and subsurface investigations, and construction specifications and documentation. Detailed specifications are also given for access road grades and paving.

Structures designed using the methodology presented by Easton et al. (1979) and Nasseri et al. (2006) have been meeting the expectations of L.A. County. However, issues are arising related to hydromodification, stream degradation, and regulatory concerns related to preserving natural systems (Willardson, 2008).

\section{PROPOSED CHANGES TO THE STATE OF PRACTICE FOR DEBRIS-FLOW BASIN DESIGN}

The intent of this paper is not to critique the design procedures published by L.A. County
(Easton et al., 1979; Nasseri et al., 2006), as these publications represent a great step forward in debrisflow mitigation engineering. However, as some of the only publications containing detailed design information, they serve as a representation of the state of practice in general and can be used as a springboard for discussion. The observations that follow should be taken as comments on the state of practice in a newly developing field and not as critiques of the pioneering work done by L.A. County. The following sections comment on potential changes to debris-basin design procedures when viewed in the context of debris-flow design recommendations presented within the technical literature. These suggestions particularly address the mitigation of fire-related debris flows and the adaptation of the design methodologies to regions beyond those used in their development. The following suggested changes to the prediction of debris-flow volume and prioritization of mitigation efforts are specific to fire-related debris flows, whereas the remaining suggestions are also applicable to non-fire-related debris flows.

\section{Predicted Debris-Flow Volume}

A predicted debris-flow volume is a rational basis for basin design, since volume will dictate the capacity of the structure and is also a good indicator of the event hazard (Jakob, 2005; Cannon, 2007). Although Nasseri et al. (2006) acknowledge that recently burned drainage basins have higher sediment production (i.e., debris-flow volumes) than unburned basins, the Debris Production curves from which a DDE is estimated are based only on sediment production from unburned drainage basins (Nasseri et al., 2006).

In areas susceptible to wildfires, the expected debris-flow volume from a recently burned watershed should also be considered. Even if a debris basin is being designed below an unburned drainage basin, it would be prudent to consider the debris-flow volume that could result if the drainage burned. Two empirical methods for the estimation of post-wildfire debris-flow volumes are discussed below. 
The Los Angeles District of the U.S. Army Corps of Engineers has developed empirical relationships for the estimation of debris production from recently burned, coastal-draining, mountainous, Southern California drainage basins (Gatwood et al., 2000). For drainage basins between $0.1 \mathrm{mi}^{2}$ and $3.0 \mathrm{mi}^{2}(0.3$ to $7.8 \mathrm{~km}^{2}$ ) in area, the debris production may be estimated by:

$$
\begin{aligned}
\log D y= & 0.65(\log P)+0.62(\log R R) \\
& +0.18(\log A)+0.12(F F)
\end{aligned}
$$

where $D y=$ debris yield $\left(\mathrm{yd}^{3} / \mathrm{mi}^{2}\right), P=$ maximum 1-hour precipitation (hundredths of an in.), $R R=$ drainage basin relief ratio (ft/mi), $A=$ drainage basin area (acres), and $F F=$ non-dimensional Fire Factor (discussed below). Note that $1 \mathrm{yd}^{3} / \mathrm{mi}^{2}=0.29 \mathrm{~m}^{3} /$ $\mathrm{km}^{2} ; 0.01$ in. $=0.25 \mathrm{~mm} ; 1 \mathrm{ft} / \mathrm{mi}=0.19 \mathrm{~m} / \mathrm{km}$; and 1 acre $=0.004 \mathrm{~km}^{2}$.

Eq. 1 was developed from nearly 350 observations and has a coefficient of determination of 0.99 . For drainage basins less than $10 \mathrm{mi}^{2}\left(26 \mathrm{~km}^{2}\right)$ in area for which peak flow data are available, the debris production may be estimated by (Gatwood et al., 2000):

$$
\begin{aligned}
\log D y= & 0.85(\log Q)+0.53(\log R R) \\
& +0.04(\log A)+0.22(F F)
\end{aligned}
$$

where $Q=$ unit peak flow $\left(\mathrm{ft}^{3} / \mathrm{s} / \mathrm{mi}^{2}\right)\left(1 \mathrm{ft} t^{3} / \mathrm{s} / \mathrm{mi}^{2}=\right.$ $0.01 \mathrm{~m}^{3} / \mathrm{s} / \mathrm{km}^{2}$ ) and all other variables are as defined in Eq. 1.

The Fire Factor used in Eq. 1 and 2 is different from the Fire Factor used in other L.A. County analyses (e.g., Willardson and Walden, 2003). Fire Factors used by the U.S. Army Corps of Engineers for debris production estimates range from 3.0 for unburned or fully recovered watersheds to 6.5 for watersheds that recently have been completely burned (100-percent wildfire). These Fire Factors can be estimated as a function of watershed size and time since a 100-percent burn by using Figures 5 or 6 . For drainage basins that are only partially burned, a weighted average of the Fire Factor is obtained based on the percentage of the basin that has been burned and the time since the burn(s), as presented in Appendix A of Gatwood et al. (2000).

Gartner et al. (2007) developed empirical models to predict debris-flow volumes from recently burned drainage basins in the western United States. The best model obtained from 50 debris-flow events in Colorado, Utah, and California was

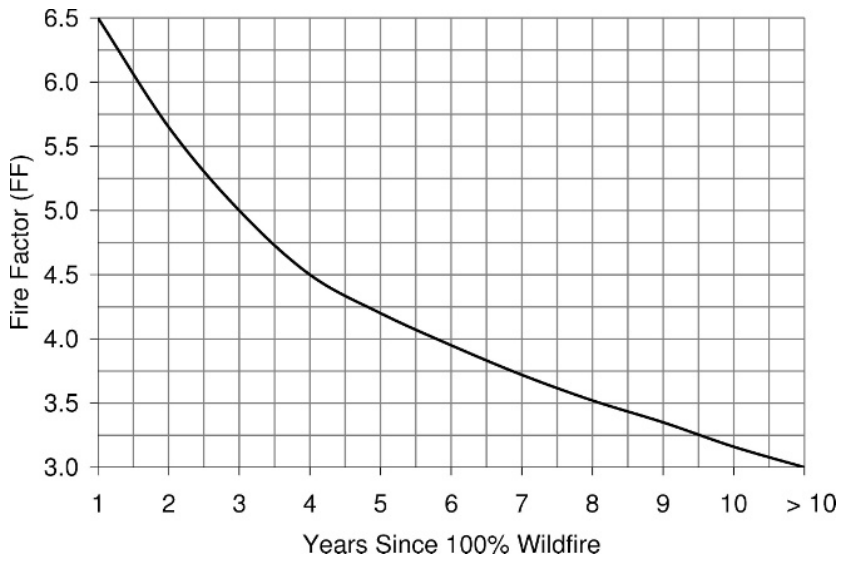

Figure 5. Fire Factor curve for watersheds between 0.1 and $3.0 \mathrm{mi}^{2}\left(0.26\right.$ and $7.8 \mathrm{~km}^{2}$ ) (after Gatwood et al., 2000).

$\ln V=0.59\left(\ln S_{30}\right)+0.65(B)^{1 / 2}+0.18(R)^{1 / 2}+7.21$

where $V=$ debris-flow volume $\left(\mathrm{m}^{3}\right), S_{30}=$ basin area with slopes greater than or equal to 30 percent $\left(\mathrm{km}^{2}\right)$, $B=$ basin area burned at moderate and high severity $\left(\mathrm{km}^{2}\right)$, and $R=$ total storm rainfall $(\mathrm{mm})$.

Eq. 3 has a coefficient of determination of 0.83 and a residual standard error of $0.79 \mathrm{ln} \mathrm{m}^{3}$ (Gartner et al., 2007).

For coastal Southern California drainages, the larger of the volumes obtained from the Corps of Engineers method (Gatwood et al., 2000) (Eq. 1 or 2) and the method of Gartner et al. (2007) (Eq. 3) could be used for design. The Corps of Engineers method will likely produce more accurate results within this region because these equations have higher coefficients of determination and are based on more observations than the method of Gartner et al. (2007). When applying the Corps of Engineers methods, it would be prudent to use a conservative Fire Factor to estimate volume, because a drainage basin may potentially become more extensively burned than its current condition. The development of Eq. 3 included debris-flow events from the Rocky Mountains, and thus this model would be more broadly applicable to regions outside of Southern California. Gartner et al. (2007) also consider burn severity in their volume prediction model and provide an estimate of modeling error.

\section{Debris Berm Specifications}

A berm crest that slopes toward the spillway is in agreement with other debris-flow basin design recommendations (Hungr et al., 1987). This will encourage any overflow to pass through the spillway 


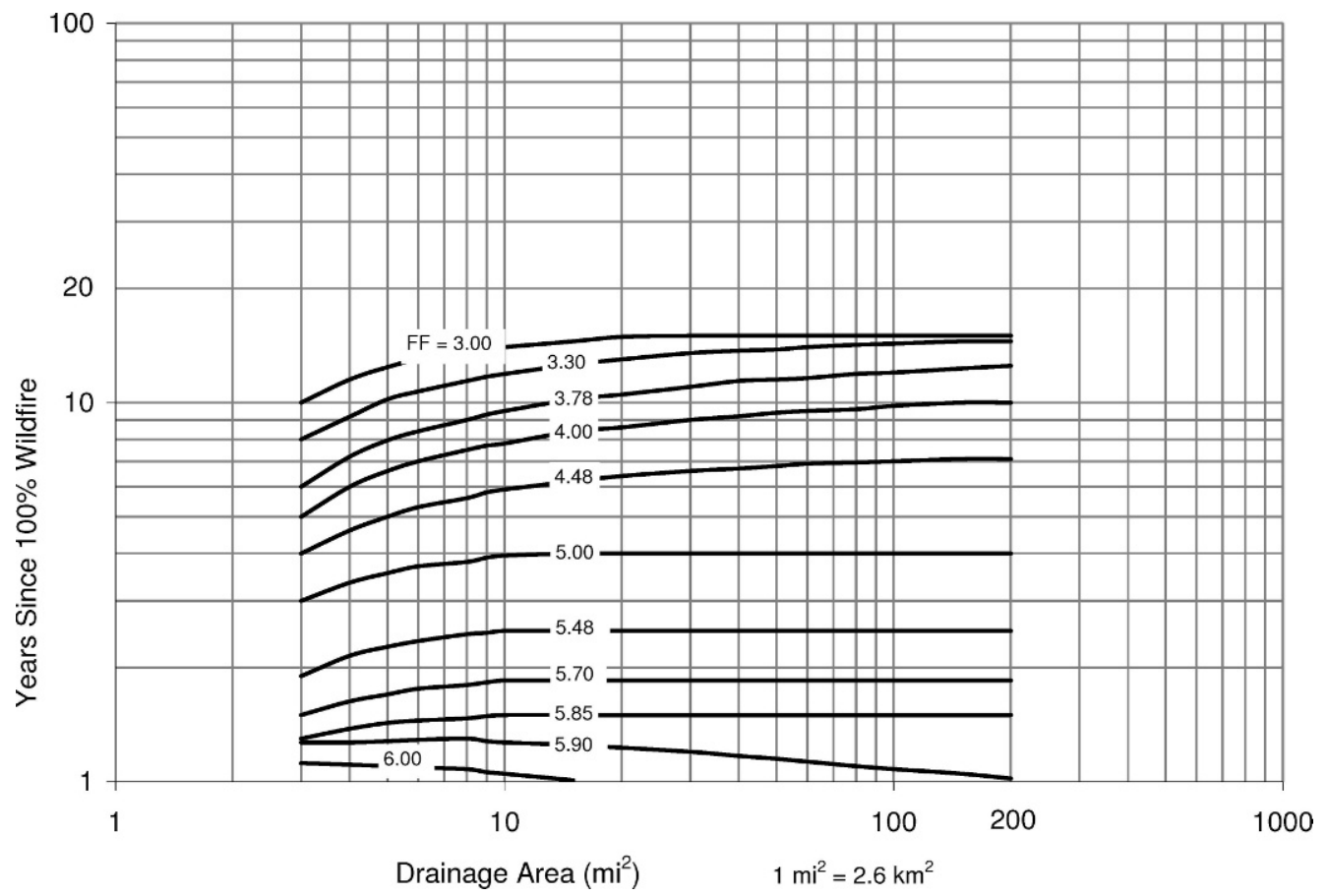

Figure 6. Fire Factor curves for watersheds between 3.0 and $200 \mathrm{mi}^{2}$ (7.8 and $520 \mathrm{~km}^{2}$ ) (after Gatwood et al., 2000).

rather than to overtop the dam, which will help to protect the berm from scour.

The recommended upstream slope of 3:1 (horizontal:vertical) may be overly conservative, given the low heights to which many debris basins will be constructed. Upstream slope stability is also aided by the specified reinforced concrete slab. A steeper upstream slope would require less fill placement during construction and would also result in greater basin capacity. Nasseri et al. (2006) report that several debris basins have experienced momentum overflow (i.e., overtopping) of the structure before the basins were filled. A steeper upstream slope may help to alleviate this problem as well.

Because laboratory soil strength testing is already required by Section B of Easton et al. (1979), it would not be overly difficult to conduct slope stability analyses. Instead of relying on a blanket specification for a 3:1 slope, the steepest upstream slope that satisfies all of the design criteria could be used.

The phenomenon that Nasseri et al. (2006) refer to as "momentum overflow" is better known in the debris-flow literature as runup. Runup is the ability of a debris flow to climb an adverse slope due to its momentum. If the runup height of a debris flow exceeds the berm height, overtopping is predicted to occur. Once a debris basin has been sized following the procedures outlined above, it should be checked that the berm is sufficiently high to resist debris-flow runup.
A commonly advocated runup prediction method (Hungr et al., 1984; Hungr and McClung, 1987; VanDine, 1996; and Lo, 2000) that has accurately matched laboratory experiments (Chu et al., 1995) is the leading-edge model:

$$
\Delta h=\frac{v^{2} \cos ^{2}\left(\theta_{0}+\theta\right) \tan \theta}{g\left(S_{f}+\tan \theta\right)}\left(1+\frac{g h \cos \theta_{0}}{2 v^{2}}\right)^{2}
$$

where: $\Delta h=$ runup height, $v=$ debris-flow velocity, $\theta_{0}=$ approach slope angle, $\theta=$ runup slope angle (berm slope), $g=$ acceleration of gravity, $S_{f}=$ friction slope, and $h=$ debris-flow depth, all in consistent units.

For runup estimations, the friction slope $\left(S_{f}\right)$ may be adequately estimated as 1.1 times the tangent of the alluvial fan slope (Rickenmann, 2005). Prochaska et al. (2008b) discuss a new method for the estimation of debris-flow velocity and the maximum probable debris-flow depth, which can be used in Eq. 4. A maximum possible flow depth, $h$, may be estimated as the height from bedrock to the top of the channel banks. This estimate conservatively assumes that, during a debris flow, the channel has been scoured down to bedrock and the channel is flowing full. An increase in flow depth above the height of the channel banks will cause material to spill over and deposit due to lack of confinement, effectively limiting the maximum potential flow depth. A debris flow velocity can be predicted preliminarily from the flow depth $(h)$ 
Prochaska, Santi, and Higgins

Table 2. Summary of velocity versus $h^{2} S$ data (from Prochaska et al., 2008b).

\begin{tabular}{lccr}
\hline \hline & $h^{2} S<3 \mathrm{~m}^{2}$ & $3 \mathrm{~m}^{2}<h^{2} S<6 \mathrm{~m}^{2}$ & $6 \mathrm{~m}^{2}<h^{2} S$ \\
\hline Mean - 1 standard deviation & $3.7 \mathrm{~m} / \mathrm{s}$ & $4.5 \mathrm{~m} / \mathrm{s}$ & $7.0 \mathrm{~m} / \mathrm{s}$ \\
Mean & $6.0 \mathrm{~m} / \mathrm{s}$ & $6.8 \mathrm{~m} / \mathrm{s}$ & $10.4 \mathrm{~m} / \mathrm{s}$ \\
Mean + 1 standard deviation & $8.3 \mathrm{~m} / \mathrm{s}$ & $9.1 \mathrm{~m} / \mathrm{s}$ & $13.8 \mathrm{~m} / \mathrm{s}$ \\
Mean + 2 standard deviations & $10.6 \mathrm{~m} / \mathrm{s}$ & $11.4 \mathrm{~m} / \mathrm{s}$ & $17.2 \mathrm{~m} / \mathrm{s}$ \\
\hline
\end{tabular}

and the sine of the channel angle $(S)$ using Table 2. This table was developed from a statistical analysis of 30 debris-flow events from the technical literature (Prochaska et al., 2008b).

No debris-berm freeboard heights are recommended by Easton et al. (1979) or Nasseri et al. (2006). Given the inherent uncertainties with debris-flow volume estimations and flow mechanics, it would seem prudent to provide an additional factor of safety to the basin capacity through a minimum freeboard requirement.

FEMA provides recommended freeboard heights for various categories of floods (Table 1) (FEMA, 1995). From Table 1, a required freeboard of at least $3 \mathrm{ft}(0.9 \mathrm{~m})$ should be provided above either the spillway elevation of the debris berm or the predicted height of runup (Eq. 4), whichever is higher. This freeboard height is comparable to those used in previous designs (Nasmith and Mercer, 1979; VanDine, 1996).

\section{Debris Barrier Specifications}

The design of the debris barrier appears to only consider the loading from water and not the impact from any debris, which is unconservative. Also, the recommended barrier spacing does not account for the site-specific debris gradation.

The debris barrier should be designed to withstand loading from the retained debris. Debris impact loads can either be estimated analytically through the loss of momentum or empirically related to hydrostatic forces. A commonly advocated analytical equation for the estimation of impact force is (Hungr et al., 1984; VanDine, 1996; and Lo, 2000):

$$
F_{d}=h * \rho * v^{2} * \sin \delta
$$

where $F=$ debris impact force per unit width of analysis, $h=$ debris-flow depth, $\rho=$ debris density, $v$ $=$ debris-flow velocity, and $\delta=$ acute angle between flow velocity vector and impacted surface, all in consistent units.

Eq. 5 assumes that the debris has zero strength. Field instrumentation and laboratory simulation of debris-flow impacts have shown that actual forces can be much larger than those predicted by Eq. 5 because of the shear strength of debris and reflection waves occurring upon impact (Lin et al., 1997; Lo, 2000). Figure 7 shows a histogram of field-measured impact forces normalized by the impact forces calculated by Eq. 5 for 24 debris-flow measurements from China (Lo, 2000). The data summarized on Figure 7 have a mean of 3.0 and a standard deviation of 1.3. Lo (2000) recommends multiplying Eq. 5 by a factor of three to obtain a design impact force.

The debris impact force can also be empirically estimated by factoring a hydrostatic load (Lo, 2000):

$$
F_{d}=\frac{\chi * \gamma_{w} * h^{2}}{2}
$$

where $F_{d}=$ debris impact force per unit width of analysis, $\chi=$ load factor, $\gamma_{w}=$ unit weight of water, and $h=$ debris-flow depth, all in consistent units.

The load factor $(\chi)$ in Eq. 6 has been recommended as being between approximately three and five (Scotton and Deganutti, 1997; Lo, 2000). Hollingsworth and Kovacs (1981) advise using an equivalent unit weight of $125 \mathrm{lb} / \mathrm{ft}^{3}\left(19.7 \mathrm{kN} / \mathrm{m}^{3}\right)$ for debris loads, which would make $\chi$ equal to two. Because of this range of suggested load factor values, a conservative load factor toward the high end of the presented ranges should be used. The flow velocity

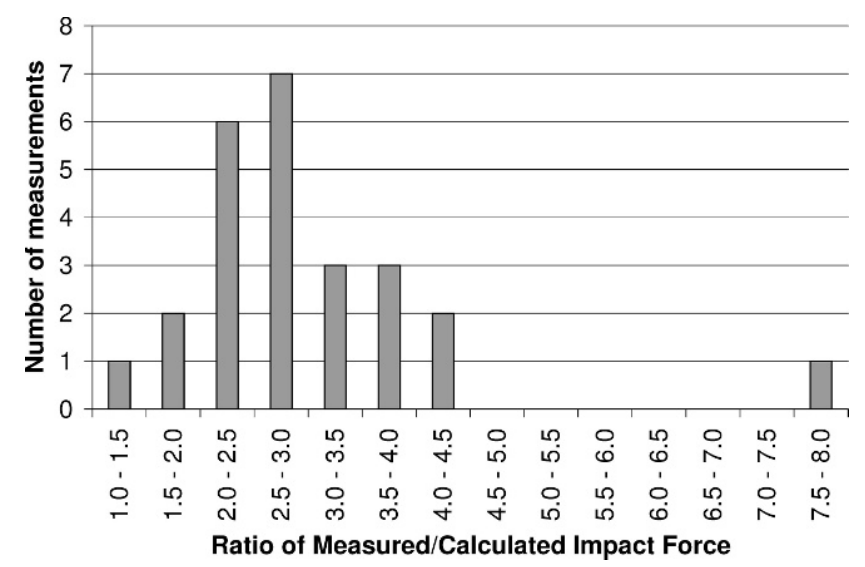

Figure 7. Histogram of the ratios of field-measured impact forces to impact forces calculated by Eq. 5 (data are from Lo, 2000). 
and depth required for debris impact force equations (Eq. 5 and 6) can be estimated as presented in Table 2 and discussed by Prochaska et al. (2008b).

In addition to debris impact forces, the debris barrier should also be designed to withstand boulder impact forces. For cantilever steel members in a debris barrier, the flexural stiffness equation would be most appropriate (Hungr et al., 1984; Johnson and McCuen, 1992; and Lo, 2000):

$$
F=v_{b} \sin \beta \sqrt{m_{b} K_{B}}
$$

$K_{B}=\frac{3 E I}{\left(\Psi L_{B}\right)^{3}} \quad$ for a cantilever beam or wall

where $F=$ impact force $(\mathrm{MN}), v_{b}=$ boulder velocity $(\mathrm{m} / \mathrm{s}), \beta=$ acute angle between the velocity vector and the barrier surface, $m_{b}=$ boulder mass $(\mathrm{Mg}), E I=$ bending stiffness of barrier $\left(\mathrm{GPa}^{*} \mathrm{~m}^{4}\right), L_{B}=$ length or height of barrier $(\mathrm{m})$, and $\Psi=$ ratio of distance between the impact location and barrier support to the length of the barrier.

The boulder velocity for use in Eq. 7 should be equal to the predicted debris-flow velocity, and the size of the design boulder should be based on the available sizes of transportable material (Hungr et al., 1984; Lo, 2000). Once the maximum impact force from Eq. 5, 6, and 7 is decided upon for design, this load should be increased by a factor of safety of 1.5 (Table 1 ).

Consideration of the site-specific debris gradation can also be incorporated into the recommended barrier spacings. In Japan, barriers are typically spaced at 1.5 to 2 times the size of the largest boulders (VanDine, 1996; Miyazawa et al., 2003). Barrier spacings used in model tests also fall within this range (Chen and Ho, 1997). This requirement could be added to the barrier spacing specifications presented previously. Channelspecific maximum particle sizes could be estimated through investigations of the sizes of material present within the channel and source areas, and also the sizes of boulders previously deposited on the fan. This evaluation of maximum particle size is also required for the estimation of boulder impact forces (Eq. 7).

\section{Outlet Works Specifications}

Easton et al. (1979) and L.A. County (2005) provide one standard outlet works design for all constructed basins, and it may be more practical to provide a few different standard designs from which to choose. Specifically, different designs should address the ability of the outlet works to convey different levels of flow and the resistance of the outlet tower to various magnitudes of impact forces.
Because Easton et al. (1979) specify that the debris barrier should be designed for loads from only clear water flow, it is likely that the standard design for the outlet tower also does not consider debris-flow impact forces. It should be verified that the existing or any future design has an appropriate factor of safety (Table 1) against the debris impact forces predicted by Eq. 5 and 6 and the boulder impact forces predicted by Eq. 7 .

Different outlet works designs should be developed for different expected impact forces. The existing standard design (L.A. County, 2005) could be used as a generic template, with specific dimensions and notes obtainable from a table based on the expected flow depth, velocity, and boulder sizes. Each design should provide a factor of safety of at least 1.5 against the expected forces (Table 1). These different designs could also provide various flow capacities within the range of discharges observed from the region's debris-flow-producing drainage basins.

\section{Miscellaneous Specifications}

An important aspect of apportioning emergency mitigation efforts is the likelihood of an individual basin to produce a debris flow. Cannon (2001) found that debris flows were not the prevalent response for 95 recently burned drainage basins in Colorado, New Mexico, and California. Only approximately 40 percent of these basins produced debris flows as their initial erosive response, and only one basin produced a debris flow in a subsequent erosional event (Cannon, 2001). Thus, in order to efficiently allocate mitigation funds, the likelihood of individual drainage basins to produce debris flows should be estimated, along with the associated hazard and risk in the event that a debris flow does occur.

The U.S. Geological Survey has developed an empirical relationship to estimate the probability of fire-related debris-flow occurrence from individual basins (Cannon et al., 2003; 2004a; 2004b):

$$
P=\frac{e^{x}}{1+e^{x}}
$$

$$
\begin{aligned}
x= & -29.693+10.697(\% \text { Burn })-9.875(\text { Sorting }) \\
& +0.208(I)+5.729(\% \text { Organics })-0.957 \\
& (\text { Permeability })+9.351(\text { Drainage }) \\
& +2.864(\% \text { GE } 30 \%)-8.335(\% \text { Burn } * \% \text { Organics }) \\
& +4.669(\text { Sorting } * \text { Drainage })-0.174(\% \text { GE30 } \% * I)
\end{aligned}
$$


Table 3. Summary of proposed changes to existing berm designs.

\begin{tabular}{|c|c|c|}
\hline Design Aspect & $\begin{array}{c}\text { State of Practice (Easton et al., } \\
\text { 1979; Nasseri et al., 2006) }\end{array}$ & Proposed Changes \\
\hline Event volume & $\begin{array}{l}\text { Sediment production from } \\
\text { unburned drainage following } \\
\text { 50-year, 24-hour rainfall }\end{array}$ & $\begin{array}{l}\text { Consider sediment production } \\
\text { from burned drainage basin }\end{array}$ \\
\hline Berm slopes & $3 \mathrm{H}: 1 \mathrm{~V}$ & $\begin{array}{l}\text { Use steepest slopes that satisfy } \\
\text { all design criteria }\end{array}$ \\
\hline Runup height & Not specified & Design berm height for anticipated debris-flow runup \\
\hline Berm freeboard & Not specified & Provide $3 \mathrm{ft}(0.9 \mathrm{~m})$ of freeboard as per FEMA (1995) \\
\hline Debris barrier spacing & $\begin{array}{l}\text { Lesser of } 4 \mathrm{ft}(1.2 \mathrm{~m}) \text { or } 2 / 3 \text { of } \\
\text { downstream conduit width }\end{array}$ & Base spacing on site-specific debris gradation \\
\hline Debris barrier loading & Designed for water load & $\begin{array}{l}\text { Consider loading from debris } \\
\text { impacts and boulder impacts }\end{array}$ \\
\hline Outlet works capacity & $150 \mathrm{ft}^{3} / \mathrm{s}\left(4.2 \mathrm{~m}^{3} / \mathrm{s}\right)$ & $\begin{array}{l}\text { Provide various designs to accommodate site-specific } \\
\text { streamflow }\end{array}$ \\
\hline Outlet works loading & Not specified & Consider loading from debris impacts and boulder impacts \\
\hline Mitigation apportioning & Not specified & $\begin{array}{l}\text { Consider debris-flow probability and associated hazards and } \\
\text { risk to allocate mitigation funds }\end{array}$ \\
\hline
\end{tabular}

where $P=$ probability of debris-flow occurrence, $\%$ Burn $=$ percent of the basin burned at high and moderate severities, Sorting $=$ sorting of the burned soil grain-size distribution (Inman, 1952), $I=$ average storm rainfall intensity $(\mathrm{mm} / \mathrm{hr}), \%$ Organics $=$ percent of soil organic matter, Permeability $=$ soil permeability (in./hr) (Schwartz and Alexander, 1995), Drainage $=$ soil drainage $($ Schwartz and Alexander, 1995), and $\% G E 30 \%=$ percent of the basin with slopes greater than or equal to 30 percent. Note: 1 in./ $\mathrm{hr}=25.4 \mathrm{~mm} / \mathrm{hr}$.

The debris-flow hazard for an individual basin can be estimated from its predicted volume and expected runout distance or inundation area. A predicted firerelated debris-flow volume can be estimated from Eq. 3. Runout or inundated area can be estimated from the ACS model (Prochaska et al., 2008a), from other existing runout estimation methods discussed by Prochaska et al. (2008a), or from developing models specific to fire-related debris flows (i.e., Bernard, 2007). Once a hazardous area has been delineated, the associated risk can be estimated from the value of the property within it. This value should consider the amount and types of development, the presence of human occupancy, and the importance of transportation corridors. Debris-flow consequence can then be estimated and ranked by multiplying each basin's risk by its probability of debris-flow occurrence (Eq. 8).

Table 3 summarizes the proposed changes to the state of practice for debris-flow basin design, as presented by Easton et al. (1979) and Nasseri et al. (2006). These changes will likely result in increased mitigation costs, the amount of which will be sitespecific. The additional cost would likely be offset by the higher safety provided by the increased mitigation effectiveness.

\section{STATE OF PRACTICE FOR DEBRIS-FLOW DEFLECTION BERM DESIGN}

\section{Oregon Department of Forestry Deflection Berm Design}

The Oregon Department of Forestry has overseen the construction of deflection berms to mitigate debris-flow hazards below logged watersheds. Rather than performing detailed analyses, qualitative judgment is conservatively applied to develop an "overengineered" design. The berms are constructed at low angles (with respect to the natural flow path), oversized, and armored with large rocks to avoid the issues of calculating runup and impact forces (Hinkle, 2007). Deflection berms designed using this methodology have not yet been tested by debris-flow events (Hinkle, 2008).

\section{NRCS Deflection Berm Design}

The NRCS office in Provo, Utah, has recently designed deflection berms for the mitigation of firerelated debris flows from Buckley Draw in Provo and Tributary 4 in Santaquin (McDonald and Giraud, 2002). Figure 8 shows a downstream view of the Buckley Draw deflection berm near Provo, Utah, following a small debris flow.

To size the deflection berms, the Provo NRCS first estimated the peak clear-water discharge from each basin using conventional hydrological methods (e.g., Brutsaert, 2005). The 25-year, 24-hour precipitation 


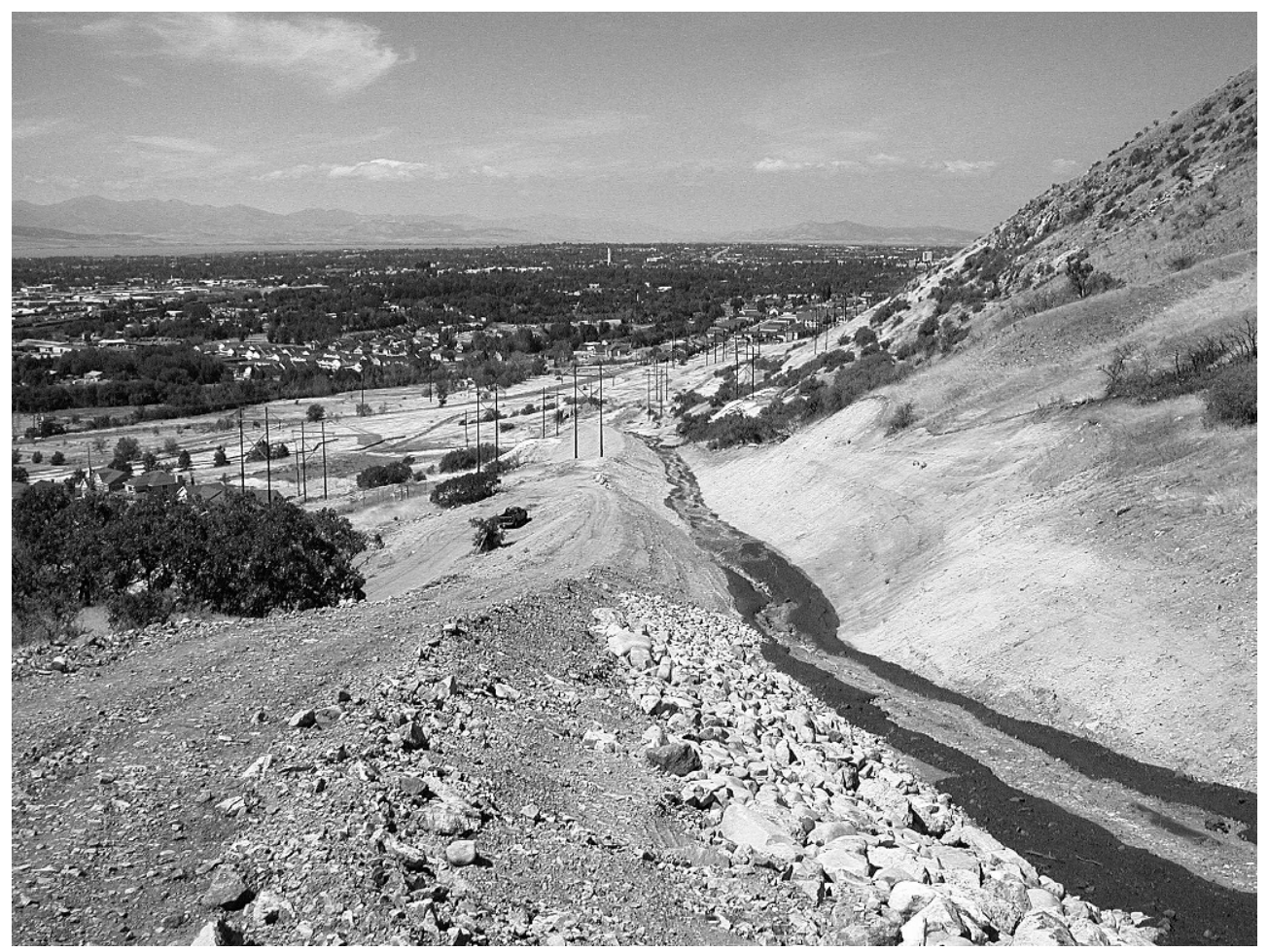

Figure 8. Downstream view of the Buckley Draw deflection berm near Provo, Utah, after a small debris flow (from Elliot, 2007).

was used for the design of the Buckley Draw deflection berm. A bulking factor was then applied to the clear-water discharge to account for the debrisflow peak discharge. For Buckley Draw, a bulking factor of approximately 1.4 was used. This bulking factor was estimated using an unpublished Engineering Technical Note developed by the NRCS in New Mexico that discusses soil erodibility. Additional conservatism and freeboard were added to the berm height above that required to pass the design discharge. Superelevation heights were also considered, and the upstream side of the berm was armored with large rocks (Rogers, 2007).

Structures designed using this methodology have settled out coarse material from debris flows, with only water and some fines exiting the structure (Rogers, 2008).

\section{PROPOSED CHANGES TO THE STATE OF PRACTICE FOR DEBRIS-FLOW DEFLECTION BERM DESIGN}

As with the critique of debris-flow basin design, the few published designs for debris-flow deflection berms are assumed to represent the state of practice in general. These published designs represent the forefront of a field that is newly developing, and the comments below are aimed at improving the state of practice and not at disparaging these designs.

\section{Discussion}

Because Oregon's Department of Forestry policy of developing conservative deflection berm designs from qualitative judgment is, by definition, subjective, it may be difficult to assess exactly what constitutes a conservative design. In order to deem a design conservative, one must have an idea of the berm size that is required to provide debris-flow control. This knowledge may come from the precedent of the successes or failures of previous structures or from a quantitative estimate of the characteristics of a design debris-flow event. Upcoming sections provide a methodology for the quantitative design of debrisflow deflection berms.

Although the NRCS designs deflection berms for a quantitative discharge, the reliance on an erodibility study from New Mexico introduces some variability. First, the applicability of this study to Utah is difficult to prove because of possible geologic, meteorologic, and vegetative differences between the two states. Second, it is uncertain whether the New Mexico erodibility study considered scouring effects of debris flows or if it was only applicable to the bulking of sediment into normal stream flow. Bulking rates observed once debris flows occur will be higher than those associated with clear-water flow due to the increased shear stress caused by a higher fluid density (Hungr et al., 2005). 
L.A. County has developed bulking factors to estimate bulked discharge from water discharge (Nasseri et al., 2006), which also introduces imprecision. The same bulking factor is applied to both burned and unburned drainage basins, when in reality a much higher sediment yield should be expected from burned drainages (Cannon and Gartner, 2005).

As discussed in the next section, a simpler method for specifying the flow capacity of a deflection berm would be to ensure that it is capable of passing at least as much flow as the channel immediately upstream from it.

\section{Proposed Guidelines}

This section presents proposed guidelines for the design of debris-flow deflection berms. These guidelines would be applicable to both fire-related debris flows and non-fire-related debris flows. Deflection structures may consist of either earthen berms or structural walls (Mears, 1981), depending on material availability. This section focuses on the design of earthen deflection berms.

\section{Berm Siting and Alignment}

The primary consideration for the design of deflection berms is the siting and alignment of the structure. Deflection berms will be most effective when they are located high on alluvial fans. Debris flows here will have higher velocities than at locations lower on fans; these higher velocities will encourage debris to pass through the deflection berm rather than depositing within it and reducing the effective height of the structure (Mears, 1981). Siting deflection berms higher on alluvial fans also enables more area to be protected, and placing a berm closer to the mountain channel lessens the chance that a debris flow could avulse and bypass the structure. However, in some cases high debris-flow velocities at the mouths of channels may make mitigation too difficult (Nasmith and Mercer, 1979), and thus berms would have to be placed lower on the fan to allow the debris flow to decelerate.

Deflection-berm alignments can be straight, curved, or a combination of the two (Mears, 1981). The siting and alignment of individual deflections berms will vary based on several site-specific considerations, including:

- The natural alignment of the stream course, and the drainage characteristics of the area.

- The topography of the alluvial fan.

- The location of the areas to be protected.
- The location of low-risk areas to where the debris can be directed.

- The anticipated characteristics of the design debrisflow event.

When designing the alignment of the berm, specific attention must be paid to where the debris flow and normal streamflow are to be directed. Consideration must be made of how the debris-flow hazard and risk to the surrounding area will change due to the deflection of the natural debris path. The deflection of the debris flow may decrease or increase its runout length and inundation area, depending on site-specific characteristics. VanDine (1996) reported that deflection berms can be aligned at low gradients to encourage deposition and reduce the runout length of debris flows. However, deflection berms may instead provide additional confinement to flowing debris and thus increase the runout length (Mears, 1981). If the deflection structure is contiguous with the mountain front and normal streamflow will be contained behind the berm, then provisions must also be made to safely direct this flow back into a natural drainage.

\section{Berm Height Sizing}

After the location and alignment of the deflection berm is decided upon, it must be appropriately sized. The berm should be high enough to pass the discharge from the design debris-flow event, with consideration given to superelevation and runup heights and an appropriate freeboard, or

$$
h_{B}=h+\Delta h+3 \mathrm{ft}
$$

where $h_{B}=$ height of debris-flow deflection berm, $h=$ depth of flow, $\Delta h=$ superelevation (Eq. 10) or runup (Eq. 4), and $3 \mathrm{ft}=$ debris-flow freeboard recommended by FEMA (Table 1) $(0.9 \mathrm{~m})$.

The superelevation height in Eq. 9 refers to the difference in surface elevation, or banking, of a debris flow as it travels around a bend. Higher velocities result in increased banking. The most commonly referenced method for making this estimation is the forced vortex equation (Eq. 10) (Johnson, 1984). A more detailed discussion of the relationship between superelevation and velocity is presented by Prochaska et al. (2008b).

$$
\Delta h=\frac{v^{2} b}{R_{c} g}
$$

where $\Delta h=$ superelevation height, $v=$ mean flow velocity, $b=$ the flow width, $R_{c}=$ radius of curvature 
of the channel, and $g=$ acceleration of gravity, all in consistent units.

Two implicit assumptions must be met for Eq. 9 to be conservative with respect to continuity of flow ( $Q$ $=v A$ ): (1) the cross-sectional area of flow behind the deflection berm is at least as large as that in the natural channel upstream of the berm and (2) the flow velocity behind the berm is similar to that in the channel upstream of the berm.

Eq. 9 assumes that the effective height of the berm is not reduced due to debris-flow deposition behind it. If deposited material is not removed from behind the berm after each debris flow, the design height of the berm should be increased by the expected depth of deposition in order to maintain adequate freeboard. The decision whether to construct a higher berm or to specify timely removal of deposited material will depend on characteristics of the debris-flow processes (frequency and magnitude of events), site considerations (e.g., material availability and ease of access), and anthropogenic factors (e.g., the responsibility of the agency managing the berm).

As discussed by Prochaska et al. (2008b), the height of the channel banks will effectively limit the maximum debris-flow depth and thus will provide a conservative estimate of $h$ for use in Eq. 9. For curved berm alignments, the value of $\Delta h$ can be obtained from Eq. 10 using a velocity predicted from Table 2 or by other methods discussed by Prochaska et al. (2008b). Use of Eq. 10 in this setting will not encounter the difficulties with the estimation of $R_{c}$ that are discussed by Prochaska et al. (2008b), because the berm alignment will be an engineered curve rather than a natural channel bend. For straight berm alignments, $\Delta h$ should be obtained from Eq. 4 following the guidelines presented above. In the case of flowing debris striking an obliquely oriented runup slope, the velocity $(v)$ used in Eq. 4 should be the slope-normal component of velocity (Mears, 1981), that is the flow velocity multiplied by $\sin \delta$ (as defined in Eq. 5).

If flow past the deflection berm is supercritical and cross-wave maxima occur at the outer bank, the superelevation in Eq. $9(\Delta h)$ could be double that predicted by Eq. 10 (Pierson, 1985). Unfortunately, it is not currently possible to predict the locations where maximum cross-wave heights will occur (Iverson, 2005). It is also not possible to design the berm to preclude supercritical flow, as cross waves that might develop higher in the natural channel are still able to continue far downstream (Chow, 1959). Thus, the deflection berm may become overtopped if maximum cross-wave heights occur on the outer bank of the bend.

Given the uncertainty in the presence and location of cross-wave interferences, it may be uneconomical to design the berm height for these sporadic increases in superelevations. If space allows, a more economical option would be to construct a second berm downslope of and parallel to the main deflection berm (e.g., Nasmith and Mercer, 1979). For berms with similar top widths and side slopes, the construction of two smaller berms with heights $h_{1}$ and $h_{2}$ will always require less fill placement than a single berm with a height of $h_{1}+h_{2}$. This second berm would provide additional security against overtopping of the first berm from cross-wave amplification or from reduced freeboard caused by the failure to remove deposited material.

\section{Berm Cross Section}

The top of the berm should be at least $10 \mathrm{ft}(3 \mathrm{~m})$ wide if it is to be used for maintenance and cleanout access (Sherard et al., 1963). A narrower top width may be used if maintenance and cleanout access is provided from behind the berm rather than from on top of it, but narrower widths will make placement and compaction of the fill near the berm crest more difficult (Fell et al., 2005).

The side slopes of a deflection berm should be sufficiently stable against all anticipated loading conditions, and steeper slopes will help to lessen the effects of runup (Eq. 4). Previous designs have used berm slopes as steep as 1.5:1 (horizontal:vertical) (Martin et al., 1984; VanDine, 1996). In Colorado a deflection berm may be classified as a Diversion Dam, and the berm slopes must conform to a minimum acceptable factor of safety of 1.3 (State of Colorado, 2007).

Earthen berms are well suited to withstand impact forces due to their large mass (Mears, 1981). To account for the impact of a debris flow, a lateral force equal to the estimated debris impact force (Eq. 5 and 6) can be applied to the upslope face of the berm during analysis of the downstream face stability. Stability of the berm against bearing capacity failure and sliding on its foundation due to the impact load should also be checked, with resulting factors of safety of at least 3 and 1.5, respectively (Das, 1999).

The downstream face of the deflection berm should be vegetated or otherwise protected to prevent erosion. The upslope face of the berm should be armored to protect it against debris-flow scour. Given the likelihood of a supply of boulders already on the debris fan, riprap may be the most economical choice for slope armoring. Riprap used to protect embankment dam slopes against wave action is sized so that it is large enough to dissipate the wave energy without being displaced (Fell et al., 2005), but if this same 
Table 4. Recommended riprap sizes for slope protection (after Sherard et al., 1963).

\begin{tabular}{cc}
\hline $\begin{array}{c}\text { Maximum Debris- } \\
\text { Flow Depth (ft) }\end{array}$ & Recommended Riprap Size (in.) \\
\hline$<4$ & 24 \\
4 to 8 & 36 \\
$>8$ & 48 \\
\hline
\end{tabular}

Notes: $1 \mathrm{ft}=0.3 \mathrm{~m}$ and 1 in. $=2.5 \mathrm{~cm}$.

criterion was applied to debris-flow slope protection the resulting particle sizes would become prohibitively large. Recommendations from Sherard et al. (1963) have been modified for debris-flow slope protection, as shown in Table 4. These riprap sizes are comparable to sizes that have been used previously to armor deflection berms (Martin et al., 1984).

The wave heights tabulated by Sherard et al. (1963) have been replaced by an expected maximum debrisflow depth in Table 4. The recommended riprap sizes in Table 4 are approximately twice as large as those presented by Sherard et al. (1963), since doubling the riprap size will result in an eight-fold increase in its resistive mass, and the load factors discussed with Eq. 5 and 6 (see also Figure 7) indicate that debrisflow impact forces can be up to eight times as large as the associated hydrostatic impacts. Because debris flows of the sizes listed in Table 4 have the capability of transporting the associated recommended riprap sizes, the riprap should be grouted or otherwise securely keyed into the berm.

The channel behind the berm should be sized to convey a range of debris flows that may be smaller than the design event; a trapezoidal channel is the best geometry for accomplishing this (Hungr et al., 1984). In order to prevent deposition of debris, the channel must provide an adequate slope and confinement. Hungr et al. (1984) report that in British Columbia deposition of channelized debris flows occurs on slopes less than 8-12 degrees. This range is in agreement with deposition-inducing slopes found in other regions (e.g., California [Campbell, 1975] and Japan [Ikeya, 1981]). Hungr et al. (1984) also recommend that the debris flow depth-to-width ratio should be greater than 0.2 to prevent deposition. Fannin and Rollerson (1993) suggest that in British Columbia deposition is more likely to occur if the channel width-to-slope ratio (meters per degree) is greater than one. While these location-specific observations should be calibrated to local conditions, they do provide items for consideration and starting values from which to base preliminary designs.

When designing the berm and the final configuration of the associated channel, it will often be advantageous to balance the volume of cut and fill so that additional soil does not need to be imported to the site. If the constructed channel is located within an earthen cut, it should be ensured that positive drainage is maintained downstream.

A generalized cross section depicting the deflection berm components is shown on Figure 9.

\section{SUMMARY AND CONCLUSIONS}

The state of practice for the design of debris-flow basins and berms has been reviewed. Published manuals for the design of debris-flow basins could be improved by incorporating the following elements:

- The expected debris-flow volumes from recently burned drainage basins should be considered when sizing a basin.

- Debris-flow runup height and FEMA's (1995) recommended freeboard should be considered when designing the upstream slope and height of the berm.

- The debris barrier should be designed to withstand impact loadings from debris and boulders rather than from just clear-water flow.

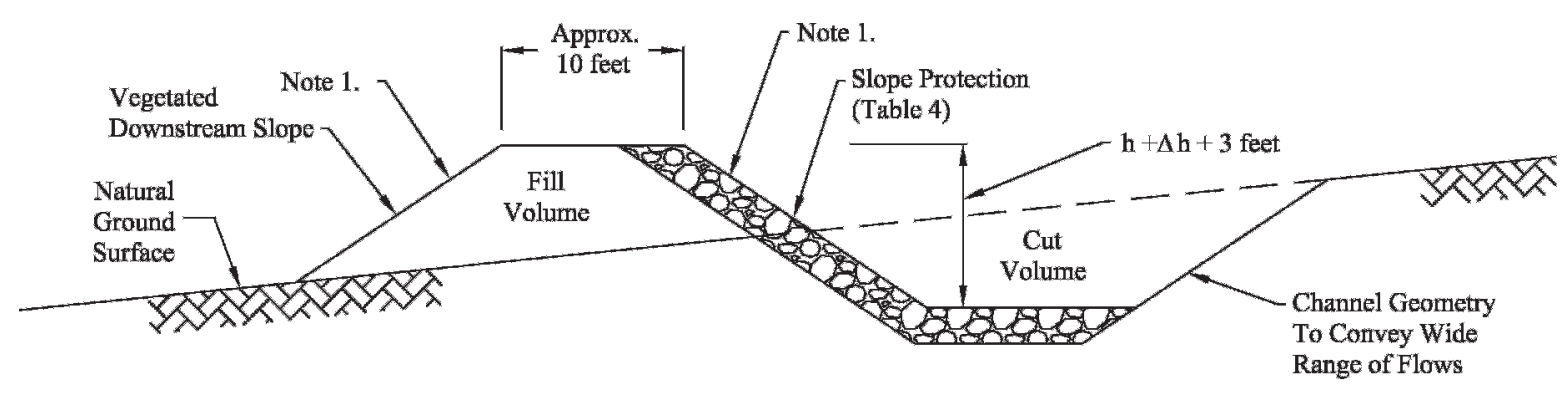

Note 1. Grade slopes to provide safety factor $>1.3$.

Figure 9. Generalized deflection berm cross section. 
- It should be verified that the outlet tower is capable of withstanding impact forces from debris and boulders.

Debris-flow deflection berms have been conservatively designed using qualitative judgment, but the degree of conservatism cannot be determined. Simple guidelines have been presented for the design of deflection berms, which include:

- Peak discharge

- Berm alignment and height

- Berm top width and side slopes

- Stability under impact loading and slope protection

- The ability to pass a range of flow rates

Although the final design of a deflection berm will be largely dictated by site-specific geometries, items to consider while aligning the berm have been presented, and the above guidelines can be used as an aid while designing representative berm sections.

\section{ACKNOWLEDGMENTS}

This work has been funded by a U.S. Department of Education Graduate Assistance in Areas of National Need (GAANN) Fellowship (award \#P200A060133). Thanks to Ben Willardson (L.A. County Flood Control-Water Resources Division), Jason Hinkle (Oregon Department of Forestry), and Steve Rogers (Provo, Utah NRCS) for providing information about their design practices.

\section{REFERENCES}

Bernard, D., 2007, Estimation of Inundation Areas of PostWildfire Debris Flows: Unpublished M.S. Thesis, Department of Geology and Geological Engineering, Colorado School of Mines, Golden, CO, 77 p.

Bradley, J. B.; Richards, D. L.; And Bahner, C. D., 2005, Debris Control Structures-Evaluation and Countermeasures. Hydraulic Engineering Circular 9, 3rd ed.: Electronic document, available at http://www.fhwa.dot.gov/engineering/hydraulics/ pubs/04016/

Brutsaert, W., 2005, Hydrology: An Introduction: Cambridge University Press, Cambridge, MA, 605 p.

Campbell, R. H., 1975, Soil Slips, Debris Flows, and Rainstorms in the Santa Monica Mountains and Vicinity, Southern California: U.S. Geological Survey Professional Paper 851, 51 p.

CAnnon, S. H., 2001, Debris-flow generation from recently burned watersheds: Environmental Engineering Geoscience, Vol. VII, No. 4, pp. 321-341.

CAnnon, S. H., 2007, personal communication on 22 May, U.S. Geological Survey, Denver, CO.

Cannon, S. H. And Gartner, J. E., 2005, Wildfire-related debris flow from a hazards perspective. In Jakob, M. and Hungr, O. (Editors), Debris-Flow Hazards and Related Phenomena: Praxis, Chichester, U.K., pp. 363-385.
Cannon, S. H.; Gartner, J. E.; Rupert, M. G.; And Michael, J. A., 2004a, Emergency Assessment of Debris-Flow Hazards from Basins Burned by the Cedar and Paradise Fires of 2003, Southern California: U.S. Geological Survey Open-File Report 2004-1011, Electronic document, available at http:// pubs.usgs.gov/of/2004/1011/

Cannon, S. H.; Gartner, J. E.; Rupert, M. G.; and Michael, J. A., 2004b, Emergency Assessment of Debris-Flow Hazards from Basins Burned by the Padua Fire of 2003, Southern California: U.S. Geological Survey Open-File Report 20041072, Electronic document, available at http://pubs.usgs.gov/ of/2004/1072/

Cannon, S. H.; Gartner, J. E.; Rupert, M. G.; Michael, J. A.; Djokic, D.; And Sreedhar, S., 2003, Emergency Assessment of Debris-Flow Hazards from Basins Burned by the Grand Prix and Old Fires of 2003, Southern California: U.S. Geological Survey Open-File Report 03-475, Electronic document, available at http://pubs.usgs.gov/of/2003/ofr-03-475/

Chen, R.-H. And Ho, M.-L., 1997, The effect of open dams on debris flows. In Chen, C.-1. (Editor), Debris-Flow Hazards Mitigation: Mechanics, Prediction, and Assessment, Proceedings of the First International Conference: ASCE, New York, pp. 626-635.

CHow, V. T., 1959, Open-Channel Hydraulics: McGraw-Hill Book Company, New York, 680 p.

Chu, T.; Hill, G.; McClung, D. M.; NGun, R.; And Sherkat, R., 1995, Experiments on granular flows to predict avalanche runup: Canadian Geotechnical Journal, Vol. 32, pp. 285-295.

DAs, B. M., 1999, Principles of Foundation Engineering, 4th ed.: PWS Publishing, Pacific Grove, CA, 862 p.

Deganutti, A. M.; Tecca, P. R.; Genevois, R.; and Galgaro, A., 2003, Field and laboratory study on the deposition features of a debris flow. In Rickenmann, D. and Chen, C.-1. (Editors), Debris-Flow Hazards Mitigation: Mechanics, Prediction, and Assessment, Proceedings of the Third International Conference: Millpress, Rotterdam, Netherlands, pp. 833-841.

Easton, J. L.; Hallstrom, C. W.; and Senzaki, K., 1979, Debris Dams and Basins Design Manual: Los Angeles County Flood Control District, Electronic document, available at http:// ladpw.org/des/Design_Manuals/

Elliot, A., 2007, Wildfires and Debris Flows in Northern Utah: Utah Geological Survey Public Information Series 90, Electronic document, available at http://geology.utah.gov/ online/pi/pi-90.pdf

Fannin, R. J. and Rollerson, T. P., 1993, Debris flows: Some physical characteristics and behaviour: Canadian Geotechnical Journal, Vol. 30, pp. 71-81.

Fell, R.; MacGregor, P.; Stapledon, D.; and Bell, G., 2005, Geotechnical Engineering of Dams: A.A. Balkema, Leiden, Netherlands, $912 \mathrm{p}$.

Fema, 1995, Engineering Principles and Practices for Retrofitting Flood Prone Residential Buildings: FEMA 259, Federal Emergency Management Agency, Electronic document, available at http://www.fema.gov/library/viewRecord.do?id= 1645

Fiebiger, G., 1997, Structures of debris flow countermeasures. In Chen, C.-1. (Editor), Debris-Flow Hazards Mitigation: Mechanics, Prediction, and Assessment, Proceedings of the First International Conference: ASCE, New York, pp. 596-605.

Gartner, J. E.; Cannon, S. H.; Santi, P. M.; and deWolfe, V. G., 2007, Empirical models to predict the volumes of debris flows generated by recently burned basins in the Western U.S.: Geomorphology, Vol. 96, pp. 310-321, doi: 10.1016/ j.geomorph.2007.02.033.

Gatwood, E.; Pedersen, J.; and Casey, K., 2000, Los Angeles District Method for Prediction of Debris Yield: U.S. Army 
Corps of Engineers Los Angeles District Hydrology and Hydraulics Branch, Los Angeles, CA.

Giraud, R. E., 2005, Guidelines for the Geologic Evaluation of Debris-Flow Hazards on Alluvial Fans in Utah: Utah Geological Survey Miscellaneous Publication 05-6, Electronic document, available at http://geology.utah.gov/online/mp/ mp05-06.pdf

Giraud, R. E. And McDonald, G. N., 2007, The 2000-2004 fire-related debris flows in northern Utah. In Schaefer, V. R.; Schuster, R. L.; and Turner, A. K. (Editors), Conference Presentations, 1 st North American Landslide Conference, Vail, Colorado: AEG Special Publication No. 23, Association of Environmental and Engineering Geologists, Denver, $\mathrm{CO}$, compact disk.

Heumader, J., 2000, Technical debris-flow countermeasures in Austria-A review. In Wieczorek, G. F. and Naeser, N. D. (Editors), Debris-Flow Hazards Mitigation: Mechanics, Prediction, and Assessment, Proceedings of the Second International Conference: AA Balkema, Rotterdam, Netherlands, pp. $553-564$.

HinkLe, J., 2007, personal communication on 30 August, Oregon Department of Forestry, Salem, OR.

HinkLE, J., 2008, personal communication on 7 February, Oregon Department of Forestry, Salem, OR.

Hollingsworth, R. and Kovacs, G. S., 1981, Soil slumps and debris flows: Prediction and protection: Bulletin Association Engineering Geologists, Vol. XVIII, No. 1, pp. 17-28.

Huebl, J. and Fiebiger, G., 2005, Debris-flow mitigation measures. In Jakob, M. and Hungr, O. (Editors), DebrisFlow Hazards and Related Phenomena: Praxis, Chichester, U.K, pp. 445-487.

Hungr, O. And McClung, D. M., 1987, An equation for calculating snow avalanche run-up against barriers. In Salm, B. and Gubler, H. (Editors), Avalanche Formation, Movement and Effects (Proceedings of the Davos Symposium, September 1986). IAHS Publication No. 162, Wallingford, Oxfordshire, UK, pp. 605-613.

Hungr, O.; McDougall, S.; And Bovis, M., 2005, Entrainment of material by debris flows. In Jakob, M. and Hungr, O. (Editors), Debris-Flow Hazards and Related Phenomena: Praxis, Chichester, U.K., pp. 135-158.

Hungr, O.; Morgan, G. C.; And Kellerhals, R., 1984, Quantitative analysis of debris torrent hazards for design of remedial measures: Canadian Geotechnical Journal, Vol. 21, pp. 663-677.

Hungr, O.; Morgan, G. C.; Vandine, D. F.; and Lister, D. R., 1987, Debris flow defenses in British Columbia. In Costa, J. E. and Wieczorek, G. F. (Editors), Reviews in Engineering Geology, Volume VII, Debris Flows/Avalanches: Process, Recognition, and Mitigation: The Geological Society of America, Boulder, CO, pp. 201-222.

IKeYA, H., 1981, A method of designation for area in danger of debris flow. In Davies, T. R. H. and Pearce, A. J. (Editors), Erosion and Sediment Transport in Pacific Rim Steeplands: IAHS Publication No. 132, Christchurch, New Zealand, pp. $576-587$.

InMAN, D. L., 1952, Measures for describing the size distribution of sediments: Journal Sedimentary Petrology, Vol. 22, No. 3, pp. $125-145$.

IVERSON, R. M., 2005, personal communication on 17 October, U.S., Geological Survey, Vancouver, WA.

JАКОВ, M., 2005, A size classification for debris flows: Engineering Geology, Vol. 79, pp. 151-161.

JAKOB, M. AND Hungr, O., 2005, Introduction. In Jakob, M. and Hungr, O. (Editors), Debris-Flow Hazards and Related Phenomena: Praxis, Chichester, U.K., pp. 1-7.
Johnson, A. M., 1984, Debris flow. In Brunsden, D. and Prior, D. B. (Editors), Slope Instability: ohn Wiley \& Sons, Chichester, U.K., pp. 257-361.

Johnson, P. A. And McCuen, R. H., 1992, Effect of debris flows on debris basin design: Critical Reviews in Environmental Control, Vol. 22, pp. 137-149.

L. A. County, 2005, Debris Dams and Basins Outlet Works, Standard Plan 3097-0: Los Angeles County Department of Public Works, Electronic document, available at http:// ladpw.org/des/Design_Manuals/

Lin, P.-S.; Chang, W.-J.; AND LiU, K.-S., 1997, Retaining function of open-type sabo dams. In Chen. and C.-1. (Editors), DebrisFlow Hazards Mitigation: Mechanics, Prediction, and Assessment, Proceedings of the First International Conference: ASCE, New York, pp. 636-645.

Lo, D. O. K., 2000, Review of Natural Terrain Landslide DebrisResisting Barrier Design: GEO Report No. 104, Geotechnical Engineering Office, Civil Engineering Department, The Government of Hong Kong Special Administrative Region, Electronic document, available at http://www.cedd.gov.hk/ eng/publications/geo_reports/index.htm

Martin, D. C.; Piteau, D. R.; Pearce, R. A.; and Hawley, P. M., 1984, Remedial measures for debris flows at the Agassiz Mountain Institution, British Columbia: Canadian Geotechnical Journal, Vol. 21, pp. 505-517.

McDonald, G. N. and Giraud, R. E., 2002, September 12, 2002, Fire-Related Debris Flows East of Santaquin and Spring Lake, Utah County, Utah: Utah Geological Survey Technical Report 02-09, Electronic document, available at http:// geology.utah.gov/online/techrpt/santaquin0902.pdf

Mears, A. I., 1981, Design Criteria for Avalanche Control Structures in the Runout Zone: General Technical Report RM-84, Rocky Mountain Forest and Range Experiment Station, USDA Forest Service, Fort Collins, CO.

Miyazawa, N.; Tanishima, T.; Sunada, K.; and Oishi, S., 2003 , Debris-flow capturing effect of grid type steel-made sabo dam using 3D distinct element method. In Rickenmann, D. and Chen, C.- 1. (Editors), Debris-Flow Hazards Mitigation: Mechanics, Prediction, and Assessment, Proceedings of the Third International Conference: Millpress, Rotterdam, Netherlands, pp. 527-538.

Nasmith, H. W. And Mercer, A. G., 1979, Design of dykes to protect against debris flows at Port Alice, British Columbia: Canadian Geotechnical Journal, Vol. 16, pp. 748 757.

Nasseri, I.; Klippel, S.; Willardson, B.; Soriano, L.; Moyer, J.; and Gaplandzhyan, M., 2006, Sedimentation Manual, 2nd ed.: Los Angeles County Department of Public Works-Water Resources Division, Electronic document, available at http:// ladpw.org/wrd/Publication/index.cfm

Pierson, T. C., 1985, Initiation and flow behavior of the 1980 Pine Creek and Muddy River lahars, Mount St. Helens, Washington: Geological Society America Bulletin, Vol. 96, pp. 1056-1069.

Prochaska, A. B.; Santi, P. M.; Higgins, J. D.; and Cannon, S. H., 2008a, Debris-flow runout predictions based on the average channel slope (ACS): Engineering Geology, Vol. 98, pp. 29-40, doi: 10.1016/j.enggeo.2008.01.011.

Prochaska, A. B.; Santi, P. M.; Higgins, J. D.; and Cannon, S. H., 2008b, A study of methods to estimate debris-flow velocity: Landslides: in press.

Rickenmann, D., 2005, Runout prediction methods. In Jakob, M. and Hungr, O. (Editors), Debris-Flow Hazards and Related Phenomena: Praxis, Chichester, U.K., pp. 305-324.

Rogers, S., 2007, personal communication on 17 September, Natural Resources Conservation Service, Provo, UT. 
Rogers, S., 2008, personal communication on 22 February, Natural Resources Conservation Service, Provo, UT.

Schwartz, G. E. And Alexander, R. B., 1995, State Soil Geographic (STATSGO) Database for the Conterminous United States: U.S. Geological Survey Open-File Report 95-449, Electronic document, available at http://water.usgs. gov/GIS/metadata/usgswrd/XML/ussoils.xml

Scotton, P. And Deganutti, A. M., 1997, Phreatic line and dynamic impact in laboratory debris flow experiments. In Chen, C.-1. (Editor), Debris-Flow Hazards Mitigation: Mechanics, Prediction, and Assessment, Proceedings of the First International Conference: ASCE, New York, pp. 777-786.

Sherard, J. L.; Woodward, R. J.; Gizienski, S. F.; and Clevenger, W. A., 1963, Earth and Earth-Rock Dams: John Wiley and Sons, New York, $725 \mathrm{p}$.

State of Colorado, 2007, Rules and Regulations for Dam Safety and Dam Construction: Department of Natural Resources, Division of Water Resources, Office of the State Engineer, Denver, CO.

Sun, H. W. And Lam, T. T. M., 2004, Use of Standardised DebrisResisting Barriers for Mitigation of Natural Terrain Landslide
Hazards: Landslip Preventive Measures Division 1 Special Project Report SPR 9/2004, Hong Kong.

Vandine, D. F., 1985, Debris flows and debris torrents in the Southern Canadian Cordillera: Canadian Geotechnical Journal, Vol. 22, pp. 44-68.

Vandine, D. F., 1996, Debris Flow Control Structures for Forest Engineering: Ministry of Forests Research Program Working Paper 08/1996, Victoria, British Columbia.

Vandine, D. F.; Hungr, O.; Lister, D. R.; and Chatwin, S. C., 1997, Channelized debris flow mitigative structures in British Columbia, Canada. In Chen, C.-1. (Editor), Debris-Flow Hazards Mitigation: Mechanics, Prediction, and Assessment, Proceedings of the First International Conference: ASCE, New York, pp. 606-615.

Willardson, B., 2008, personal communication on 11 February, Los Angeles County Department of Public Works-Water Resources Division, Alhambra, CA.

Willardson, B. And Walden, A., 2003, Development of Burn Policy Methodology (Santa Clara River Watershed Pilot Program): Los Angeles County Department of Public Works-Water Resources Division, Alhambra, CA. 